\title{
Indikasi Mineralisasi Tipe Porfiri di Daerah Sumbersari, Kompleks Pengunungan Kulon Progo, Purworejo, Indonesia
}

\section{Indication of Porphyry Type Mineralization at Sumbersari Area, Kulon Progo Mountain Complex, Purworejo, Indonesia}

\author{
Okki Verdiansyah $^{1} *$, Damas Muharif ${ }^{1}$, I Gde Sukadana $^{2}$ \\ ${ }^{1}$ Teknik Geologi Institut Teknologi Nasional Yogyakarta (ITNY), \\ Jl. Babarsari, Tambak Bayan, Depok, Sleman, Daerah Istimewa Yogyakarta, Indonesia, 55281 \\ ${ }^{2}$ Pusat Teknologi Bahan Galian Nuklir-BATAN \\ Jl. Lebak Bulus Raya No.9 Pasar Jumat, Jakarta, Indonesia, 12440 \\ *E-mail: okki.verdiansyah@itny.ac.id
}

Naskah diterima: 12 Juli 2020, direvisi: 20 Juli 2020, disetujui: 21 Juli 2020

DOI: 10.17146/eksplorium.2020.41.2.5959

\begin{abstract}
ABSTRAK
Pegunungan Kulon Progo merupakan produk magmatisme Busur Sunda-Banda tersusun atas formasi andesit tua. Daerah Sumbersari merupakan bagian dari gunung api Gajah, batuan gunung api tertua Kulon Progo. Indikasi mineralisasi tipe porfiri ditemukan di daerah ini sehingga menarik untuk diteliti lebih lanjut. Penelitian ini bertujuan untuk mengetahui potensi keterdapatan mineral logam berharga $(\mathrm{Cu}-\mathrm{Au})$. Metode penelitian yang digunakan adalah pemetaan geologi, analisis petrografi dan mikroskopi bijih, serta analisis geokimia menggunakan XRF dan ICP-MS. Geologi daerah penelitian terletak pada fasies sentral-proksimal Khuluk Gajah, terususun atas intrusi mikrodiorit, mikrodiorit kuarsa, andesit, andesit basaltik-diorit, dan batugamping. Alterasi hidrotermal berkembang pada batuan beku diorit, mikrodiorit, dan sebagian pada andesit. Alterasi hidrotermal dibagi menjadi beberapa kelompok, yaitu ilit-serisit \pm biotit sekunder, epidot-aktinolit-kalsit \pm ilit, epidot-kalsit \pm ilit, dan ilit-serisit \pm kuarsa. Beberapa fase mineralisasi berkembang, antara lain fase epidot-aktinolit yang diikuti mineralisasi magnetit-kalkopirit, fase biotit-magnetit-kalkopirit-bornit, dan fase akhir serisit-mineral lempungpirit menggantikan keseluruhan sistem. Analisis geokimia pada batuan teralterasi menunjukan indikasi mineralisasi $\mathrm{Cu}$ - $\mathrm{Au}$ dengan kadar 491-1447 ppm (0,14\%) $\mathrm{Cu}$ dan 0,02-0,3 ppm Au dengan rasio elemen $\mathrm{Cu}: \mathrm{Au}$ adalah 1,01. Karakter geokimia menunjukkan adanya korelasi kuat $\mathrm{Cu}$ terhadap $\mathrm{Au}$.
\end{abstract}

Kata kunci: indikasi, mineralisasi, emas, tembaga, tipe porfiri, Kulon Progo

\begin{abstract}
Kulon Progo Mountain is Sunda-Banda Arc magmatism product composed of an old andesite formation. Sumbersari Area is part of the Gajah volcanic, which is the oldest rock of Kulon Progo volcanics. Indication of porphyry type mineralisation has been found in the area which makes the area interested for further research. The research methodologies are geological mapping, petrography and ore microscopy, and geochemical analysis using XRF and ICP-MS. Geology of the area located in central-proximal facies of Khuluk Gajah, consist of microdiorite, quartz-microdiorite, andesite, basaltic-dioritic andesite intrusions, and limestone. Hydrotermal alteration is developing into certain groups like illite-sericite \pm secondary biotite, epidote-actinolite-calcite \pm illite, epidot-calcite \pm illite, and illite-sericite \pm quartz. Some mineralisation phases are developed like epidoteactinolite followed by magnetite-chalcopyrite mineralisation, biotite-magnetite-chalcopyrite-bornite phase and the late phase of sericite-clay-pyrite replacing the entire system. Geochemical analysis on altered rocks show $\mathrm{Cu}$ Au mineralisation indication ranging from 491-1,447 ppm (0.14\%) and 0.02-0.3 ppm respectively, with Cu:Au ratio is 1.01. Geochemical characteristic shows strong correlation of $\mathrm{Cu}$ to $\mathrm{Au}$.
\end{abstract}

Keywords: indication, mineralization, gold, copper, porphyry type, Kulon Progo. 


\section{PENDAHULUAN}

Sabuk Sunda bagian timur merupakan sabuk tektonik dengan keterdapatan mineralisasi yang sangat baik dan berkelas dunia [1]. Saat ini telah ditemukan beberapa deposit besar tipe porfiri seperti Batu Hijau dan Elang [2], Brambang [3], Tumpang Pitu [4], serta ditemukannya deposit baru seperti Hu'u [5] dan Selogiri [6]. Deposit itu berasosiasi dengan sabuk tektonik dan magmatisme berumur Miosen sampai Pleistosen dan berhubungan dengan magmatisme Pegunungan Selatan. [1, 7].

Batuan gunung api Kulon Progo merupakan bagian dari magmatisme Busur Sunda-Banda. Batuan tersebut merupakan bagian dari formasi gunung api tua andesit (Old Andesite Fomation). Magmatisme daerah ini terbentuk pada Oligosen hingga Miosen (30-8 jtl) [8] dengan batasan yang belum jelas sampai saat ini. Mineralisasi logam berharga di Jawa umumnya berhubungan dengan vulkanik dan tektonik seperti pada deposit dan prospek epitermal di Jawa [9] dan bahkan kemungkinan pada berbagai tipe porfiri yang tersebar di Sabuk Sunda (Gambar 1.a).

Potensi mineralisasi emas tipe epitermal di Pegunungan Kulon Progo ditemukan di daerah Kokap (Kulon Progo), Bagelen (Purworejo), Gupit (Magelang), dan Loano (Purworejo) berupa urat (vein) dan diseminasi berasosiasi dengan sulfida [10-12]. Hal tersebut menunjukkan bahwa selain di Pegunungan Selatan, potensi mineralisasi emas juga ditemukan di Pegunungan Kulon Progo. Oleh karena itu, perlu dilakukan penelitian yang lebih detil untuk mendapatkan cebakan yang bernilai ekonomis.
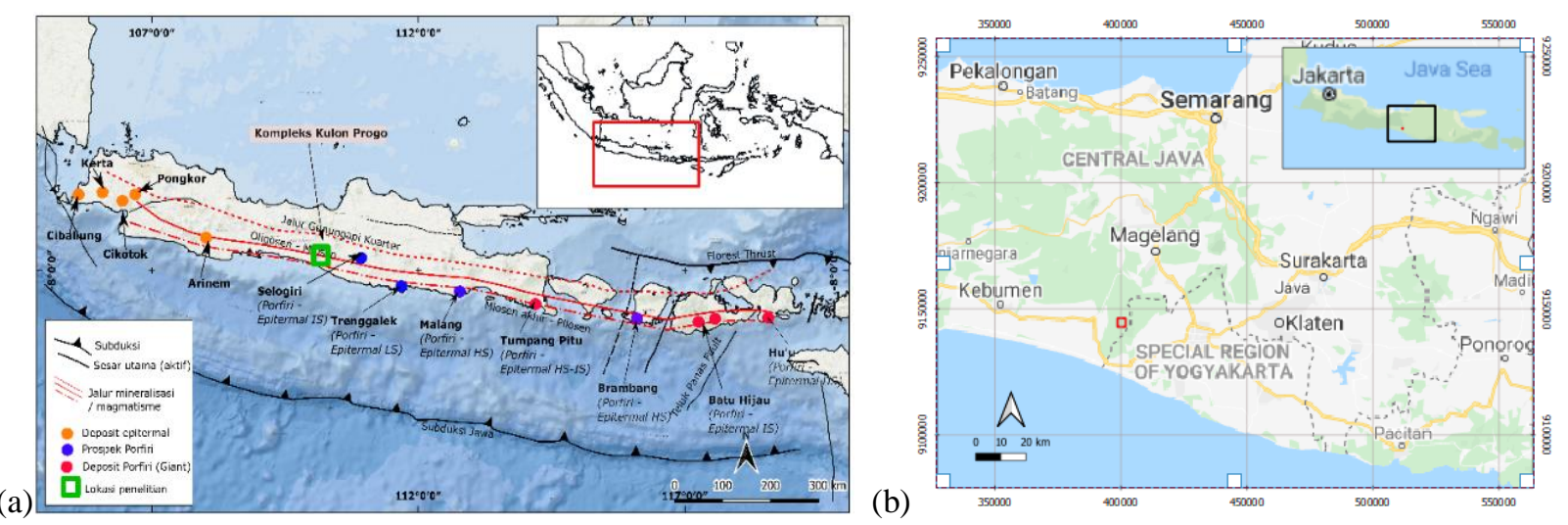

Gambar 1.(a) Sebaran mineralisasi pada sabuk Sunda bagian timur [1, 7]; dan (b) lokasi penelitian.

Daerah penelitian terletak di Desa Sumbersari, Kecamatan Kaligesing, Kabupaten Purworejo, Jawa Tengah yang merupakan bagian barat dari Pegunungan Kulon Progo (Gambar 1.b). Indikasi mineralisasi yang cukup menarik ditemukan di daerah ini berupa mineralisasi tembagaemas porfiri pada singkapan batuan dioritik meskipun hanya setempat [13]. Penelitian ini bertujuan untuk mengetahui potensi keterdapatan mineral logam berharga $(\mathrm{Cu}-$ $\mathrm{Au})$ di daerah tersebut melalui penelitian lebih lanjut.

\section{GEOLOGI KULON PROGO}

Daerah Kulon Progo merupakan bagian dari jalur magmatisme dekat dengan Pegunungan Selatan Jawa yang terbukti memiliki kehadiran mineralisasi emastembaga yang berharga. Sebaran mineralisasi 
porfiri di Jawa tercatat baik berada di Selogiri (Wonogiri, Jawa Tengah) dan Tumpang Pitu (Banyuwangi, Jawa Timur) serta beberapa prospek porfiri yang hadir seperti Trenggalek dan Malang (Gambar 1.a). Magmatisme di daerah Kulon Progo merupakan seri magma kalk-alkali dengan komposisi andesit basaltik sampai dasit yang terjadi dalam dua periode, yaitu Oligosen Akhir-Miosen Awal (25,429,6 jtl) dan pada Miosen Akhir (8,1 1 1,19 jtl) [14].

Geologi daerah penelitian memiliki kemiripan dengan magmatisme, vulkanisme, dan sedimentasi daerah Pegunungan Selatan. Pegunungan Selatan sebagian besarnya merupakan kompleks gunung api yang membentuk gumuk, khuluk dan bregada, serta beberapa kaldera purba [15]. Batuan beku dalam kompleks gunung api tersebut mempunyai umur berkisar Oligosen-Miosen, yang pada peta geologi regional disebut sebagai Old Andesite Formation (OAF) pada sisi barat seperti Kulon Progo dan Godean, serta disebut Mandalika pada bagian timurnya. Magmatisme Pegunungan Selatan yang kemungkinan serupa dengan Godean adalah pada umur 11,3-17,2 Jtl seperti Gajahmungkur (Wonogiri), Gunung Ijo (Kulon Progo), dan Menoreh (Magelang), disertai tahapan mineralisasi pada bagian fasies pusat erupsinya. Berdasarkan pola sebaran magmatisme Tersier di Pegunungan Selatan Jawa, maka daerah Godean diinterpretasi mempunyai kisaran umur dan gejala magmatisme bahkan tektonik yang serupa.

Secara regional, batuan tertua dimasukkan ke dalam Formasi Nanggulan (Teon) yang berumur Eosen, tersusun atas sisipan lignit, napal pasiran, batulempung dengan konkresi limonit, sisipan napal dan batugamping, batupasir, dan tuf. Formasi Kebobutak (Tmok) tersusun atas breksi andesit, tuf, tuf lapili, aglomerat, dan aliran lava andesit berumur Oligo-Miosen. Kedua satuan batuan tersebut kemudian diterobos oleh diorit (dr) dan andesit (a) berumur Miosen Bawah (Gambar 2) [16].

Struktur geologi pada batuan berumur Paleogen, terutama di daerah Godean terlihat membentuk pola jajaran genjang sebagai gabungan struktur berarah barat-timur dan utara-selatan yang membentuk graben Yogyakarta-Bantul [17]. Selain itu, struktur geologi daerah ini membentuk pola tektonik berupa sesar berarah selatan-barat laut dan sesar turun berarah barat-timur [18].

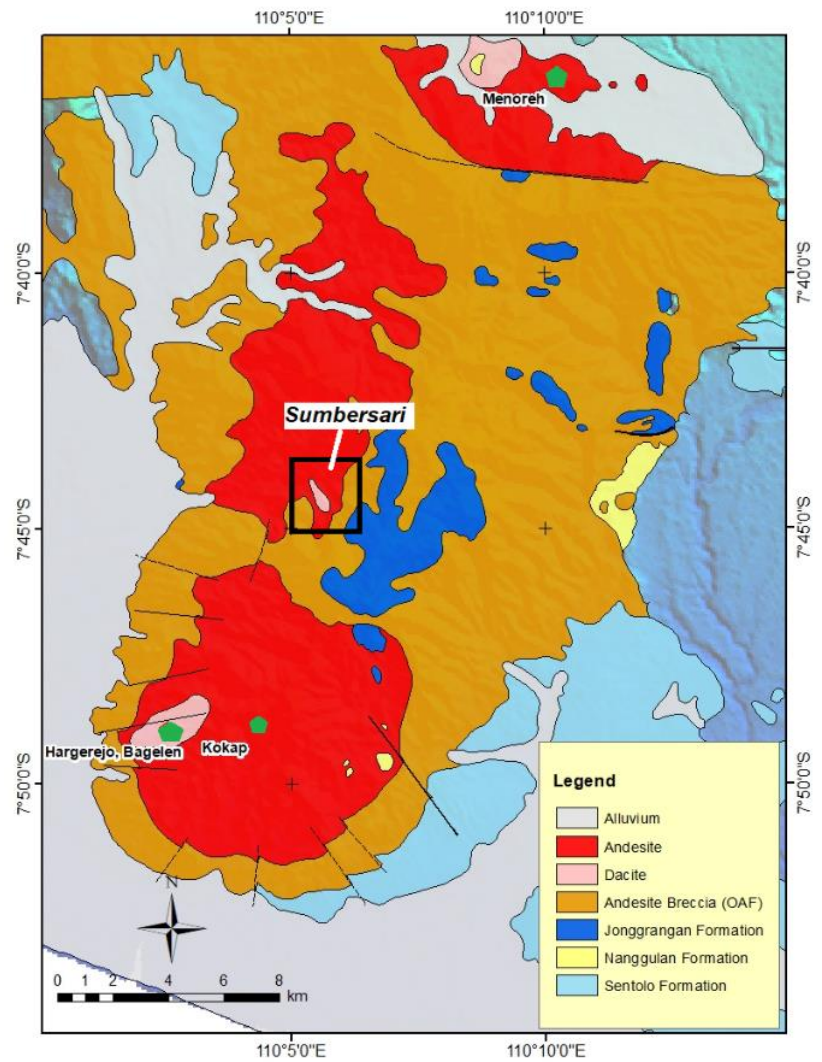

Gambar 2. Peta geologi regional Kulon Progo [16] dan keterdapatan mineralisasinya. Lokasi penelitian berada pada daerah Sumbersari (kotak hitam).

Morfotektonik Pegunungan Kulon Progo mempunyai arah relatif utara-timur laut yang juga sepola dengan sesar Progo-Muria. Karakter kelurusan sesar dan Pegunungan Kulon Progo diinterpretasi sebagai bagian 
dari batas lempeng kontinen di Pegunungan Selatan Jawa [19] dan produk perubahan sesar transform sebagai akibat dari pergeseran mikrokotinen [20]. Secara umum, pola Pegunungan Kulon Progo dipengaruhi oleh kompresi utara-selatan yang menghasilkan sesar mengiri (sinistral) dengan pola kelurusan pegunungan timur laut-barat daya. Pada Khuluk Gajah, morfologi dan magmatisme dipengaruhi oleh sesar naik dan normal yang membentuk runtuhan pada sisi baratnya [21].

Daerah Kulon Progo setidaknya memiliki lima area target daerah mineralisasi, yaitu (1) Bagelen, (2) Kokap, (3) Kaligesing, (4) Loano, dan (5) Wadas [13]. Semua target mineralisasi terbentuk pada pusat erupsi terbelakang, berasosiasi dengan fasies pusat dan proksimal dari setiap gumuk yang terbentuk. Karakteristik mineralisasi diinterpretasi berhubungan dengan tipe epitermal sulfidasi rendah sampai tinggi, dengan asosiasi tipe porfiri $\mathrm{Cu}-\mathrm{Au}$ di bawah permukaannya.

\section{METODOLOGI}

Metode penelitian yang digunakan adalah pendataan data permukaan melalui pemetaan geologi dengan skala 1:25.000. Pemetaan geologi ini meliputi pemetaan alterasi dan identifikasi mineralisasi di beberapa cabang sungai dan singkapan yang berada di lereng bukit. Pengambilan sampel batuan dilakukan untuk menganalisis mineraloginya melalui analisis petrografi dan mikroskopi bijih (mineragrafi). Analisis tersebut dilakukan di Laboratorium Mineral Petrologi ITNY.

Selain pengamatan dengan menggunakan mikroskop, analisis juga dilengkapi dengan geokimia kadar unsur batuan. Analisis geokimia menggunakan metode Inductively Coupled Plasma Optical Emission
Spectroscopy (ICP-OES) di Laboratorium Kimia Unit Geomin PT. Antam (Persero) Tbk.

\section{HASIL DAN PEMBAHASAN \\ Geologi daerah Penelitian}

Daerah penelitian terletak di fasies sentral-proksimal dari Khuluk Gajah yang tersusun atas intrusi mikrodiorit, mikrodiorit kuarsa, andesit, intrusi andesit basaltik-diorit, dan batugamping (Gambar 3). Satuan batuan tersebut adalah bagian dari Formasi Kebobutak yang berumur Oligosen-Miosen (Tmok) dan Formasi Jonggrangan (Tmj). Satuan tertua diperkirakan berupa lava andesit yang diintrusi oleh mikrodiorit, mikrodiorit kuarsa, andesit, andesit basaltik-diorit, dan ditutupi oleh tubuh batugamping yang berumur lebih muda.

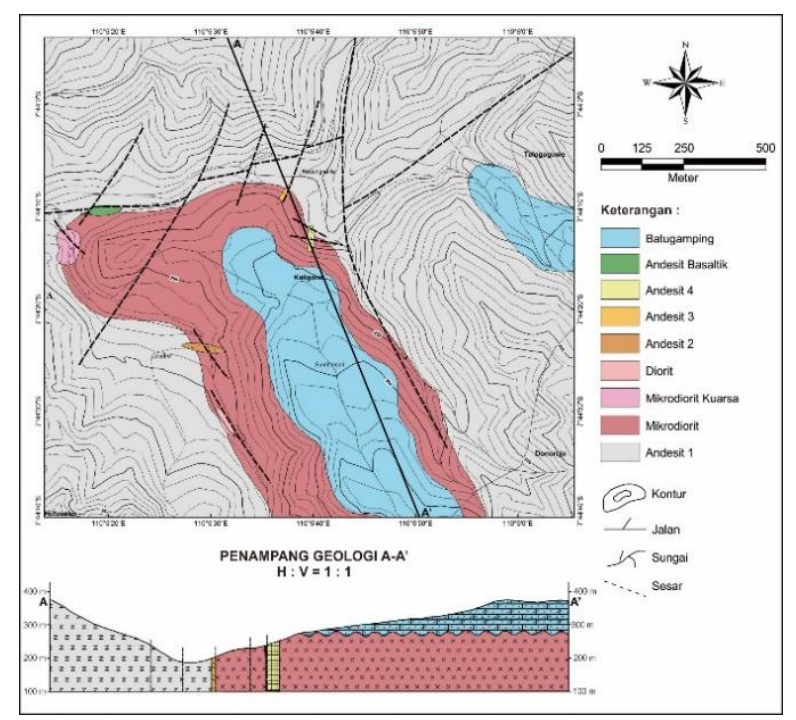

Gambar 3. Peta geologi daerah penelitian.

Satuan andesit 1 diinterpretasikan sebagai satuan tertua yang dijumpai di permukaan dan tersebar sangat luas. Satuan ini disusun oleh andesit masif berwarna abuabu kehijauan, massa dasar afanitik lebih dominan daripada fenokris, ukuran kristal halus, tekstur porfiritik (Gambar 4). Komposisi mineral berupa fenokris plagioklas, hornblenda, dan mineral ubahan 
berupa klorit dan epidot, serta mineral sulfida dominan berupa pirit.

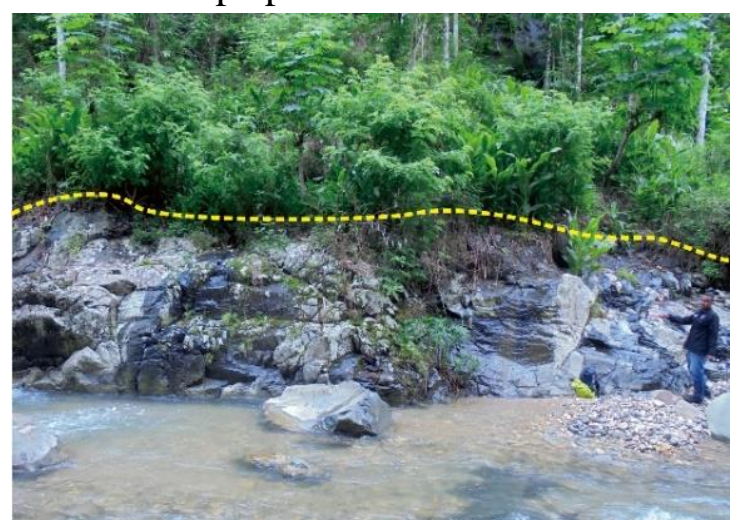

Gambar 4. Singkapan lava andesit yang ada di daerah penelitian.

Satuan mikrodiorit menerobos satuan andesit 1. Satuan ini diperkirakan menjadi tubuh intrusi utama yang ada di daerah penelitian. Mikrodiorit tersingkap pada bukit di daerah Kaligono berarah barat lauttenggara. Berdasarkan pengamatan secara megaskopis, litologi penyusun satuan ini memiliki struktur masif, warna abu-abu gelap, ukuran kristal dominan fanerik sedang-halus, dan tekstur porfiritik. Komposisi mineral berupa plagioklas, hornblenda, magnetit, dan diseminasi pirit. Satuan ini merupakan batuan inang mineralisasi dengan bukti dijumpai beberapa tipe urat kuarsa yang hadir sebagai stockwork maupun sheeted vein berupa vein tipe $\mathrm{A}, \mathrm{AB}$ family vein, sheeted $\mathrm{B}$ vein, dan vein tipe $\mathrm{D}$ (Gambar 5).

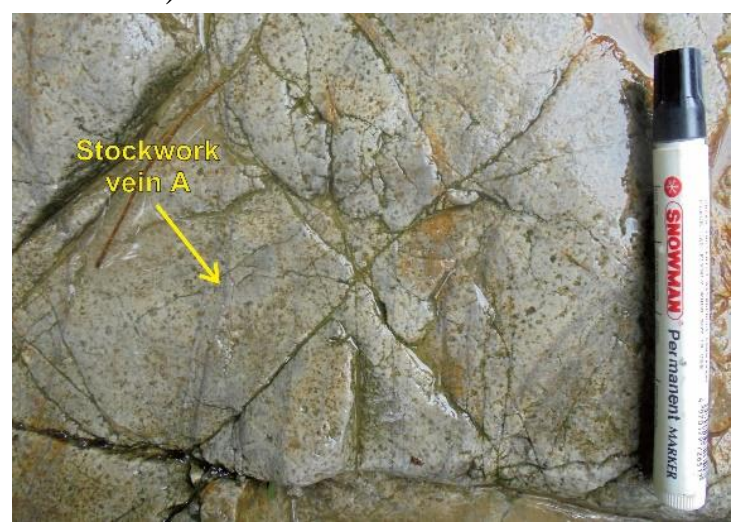

Gambar 5. Singkapan mikrodiorit yang ada di daerah penelitian yang berasosiasi dengan stockwork vein A.
Satuan mikrodiorit kuarsa hanya tersingkap secara setempat di sebelah barat tubuh intrusi utama mikrodiorit. Satuan ini diperkirakan memotong satuan andesit 1 dan satuan mikrodiorit. Litologi penyusun satuan ini memiliki struktur masif, warna abu-abu cerah sampai kehijauan, ukuran kristal dominan fanerik sedang-halus, dan bertekstur porfiritik. Komposisi mineral utama berupa plagioklas, kuarsa, epidot, klorit, dan diseminasi pirit.

Satuan diorit hadir sebagai retas yang memotong tubuh satuan mikrodiorit dan satuan andesit 1 (Gambar 6). Berdasarkan pengamatan di lapangan, litologi penyusunnya memiliki struktur masif, warna abu-abu cerah, berukuran kristal fanerik sedang-kasar, bertekstur hipidiomorfik granular. Komposisi mineral berupa plagioklas, mineral opak, dan kalsit.

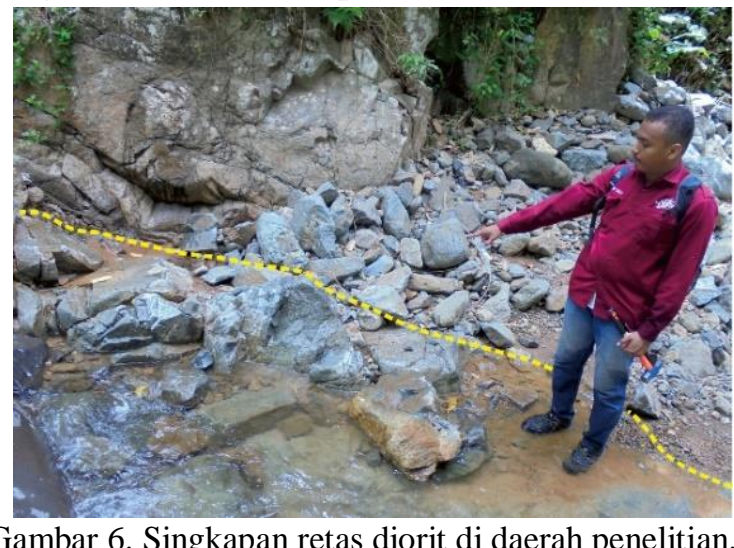

Satuan andesit 2 hadir sebagai tubuh batuan yang memotong satuan mikrodiorit dan satuan andesit 1 di sebelah barat daya tubuh intrusi mikrodiorit. Satuan andesit ini berwarna abu-abu kehijauan, struktur masif, ukuran kristal dominan fanerik halusafanitik, dan bertekstur porfiroafanitik. Komposisi mineral utama berupa plagioklas, klorit, hematit, dan massa dasar berupa gelas.

Satuan andesit 3 hadir sebagai retas yang memotong satuan mikrodorit dan satuan andesit 1 yang berada di sebelah utara tubuh 
intrusi mikrodiorit. Satuan ini memiliki struktur masif, warna abu-abu kecoklatan, ukuran kristal fanerik halus-afanitik, dan bertekstur porfiro-afanitik. Komposisi utama berupa mineral plagioklas, hematit, dan mineral opak.

Satuan andesit 4 sebagai retas yang memotong satuan mikrodiorit dan satuan andesit 1 yang berada di sebelah timur tubuh intrusi mikrodiorit (Gambar 7). Satuan ini memiliki struktur masif, warna abu-abu kehijauan, ukuran kristal fanerik halusafanitik, bertekstur porfiroafanitik. Komposisi mineral utama berupa plagioklas, klorit, epidot, dan massa dasar berupa gelas.

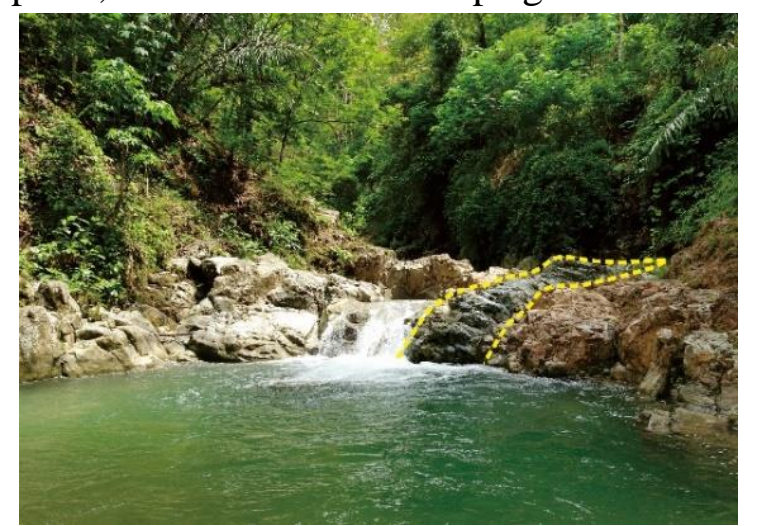

Gambar 7. Singkapan retas andesit yang ada di daerah penelitian.

Satuan andesit basaltik hadir sebagai retas yang memotong satuan andesit 1 dan satuan mikrodiorit yang berada di sebelah barat laut intrusi mikrodiorit. Satuan ini memiliki struktur masif, warna abu-abu kehijauan, ukuran kristal fanerik halusafanitik, tekstur porfiroafanitik. Komposisi mineral utama berupa plagioklas, klorit, mineral opak, dan massa dasar berupa gelas.

Satuan batugamping rudstone diinterpretasikan memiliki umur paling muda di antara satuan batuan yang ada di daerah penelitian (Gambar 8). Batugamping berada di atas batuan beku secara tidak selaras, tetapi belum dijumpai singkapan yang jelas kontaknya. Secara umum, batugamping memiliki struktur masif, warna cokelat kehitaman, ukuran butir pasir sangat kasarbongkah, kemas terbuka, sortasi buruk, komposisi mineral dominan berupa litik batugamping, fosil, dan kalsit.

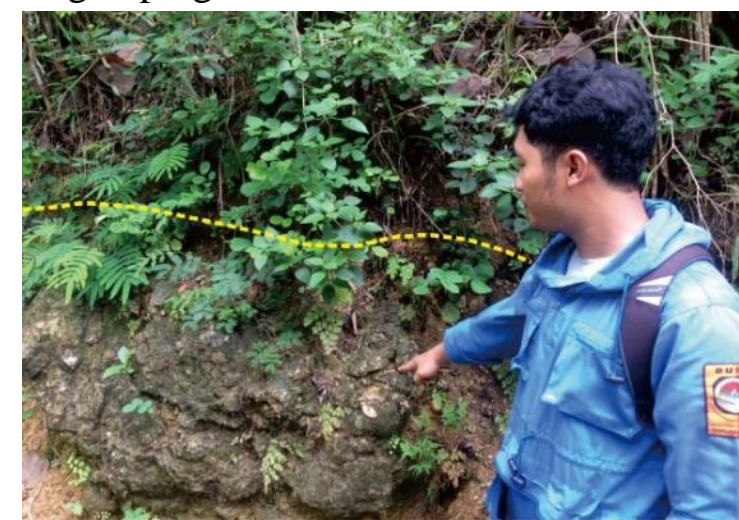

Gambar 8. Singkapan batugamping yang ada di daerah penelitian.

Struktur geologi yang dominan memiliki arah relatif timur laut-barat daya, barat lauttenggara, dan barat-timur yang ada di sekitar tubuh intrusi mikrodiorit. Hal ini diduga memiliki peran penting untuk mengontrol dan menjadi jalur aktivitas fluida hidrotermal di daerah penelitian.

\section{Alterasi Hidrotermal}

Alterasi hidrotermal berkembang pada batuan beku diorit, mikrodiorit, dan sebagian andesit. Singkapan alterasi hidrotermal dijumpai pada sungai dan alur kecil di daerah penelitian, sebarannya masih sangat terbatas sehingga untuk menentukan batas alterasi masih membutuhkan penelitian yang lebih sistematik. Secara umum, alterasi menyebar sangat merata dan terlihat memiliki karakter yang berasosiasi dengan tipe porfiri, seperti hadirnya tipe potasik dan propilitik dalam. Alterasi hidrotermal yang berkembang dapat dibagi menjadi beberapa kelompok, yaitu ilitserisit \pm biotit sekunder, epidot-aktinolitkalsit \pm ilit, epidot-kalsit \pm ilit, dan ilitserisit \pm kuarsa (Gambar 9). 


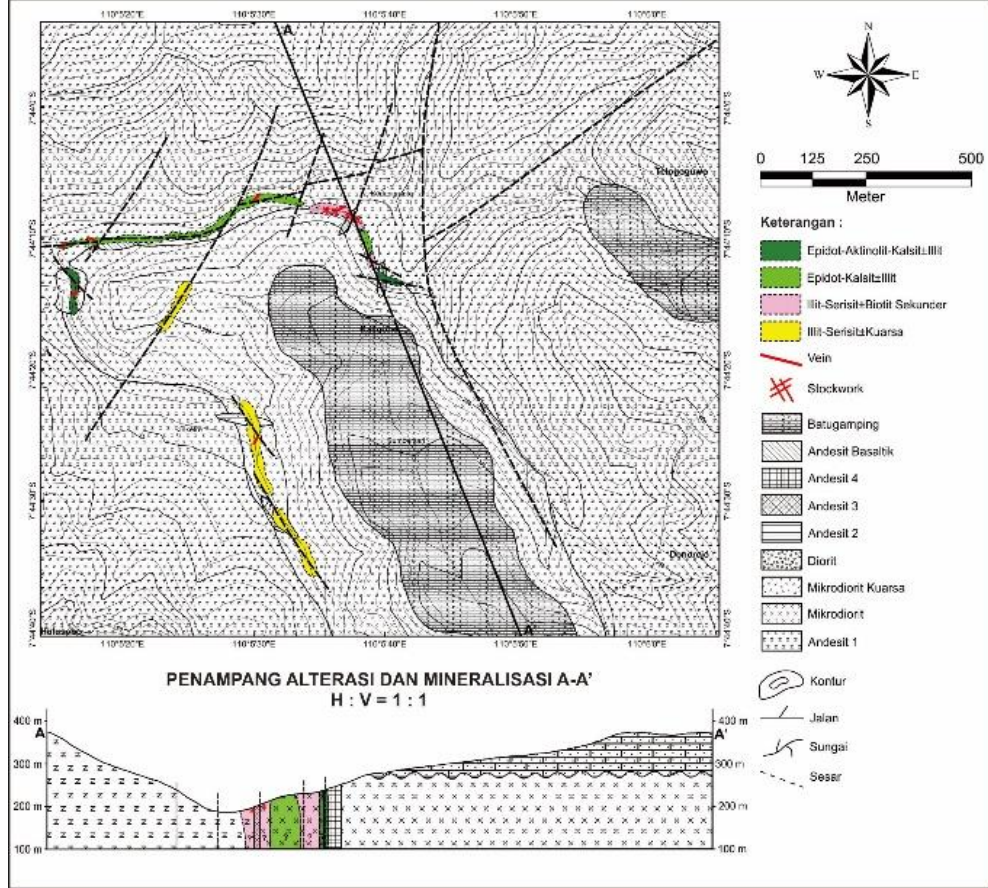

Gambar 9. Peta alterasi dan mineralisasi daerah penelitian. Interpretasi sebarannya belum dapat dilakukan pada tahapan ini.

\section{Mineralisasi}

Mineralisasi yang berkembang berasosiasi dengan kehadiran urat kuarsa tipe porfiri, bertekstur stockwork dan sheeted. Urat yang berkembang umumnya tipe A dan AB yang berukuran halus hingga beberapa millimeter. Urat lain hadir berupa urat kalkopirit atau tipe $\mathrm{C}$ dan urat pirit yang merupakan implikasi kehadiran tipe epitermal pada batuan ini (gambar 10). Batuan induk yang terkena mineralisasi merupakan batuan diorit-mikrodiorit dengan alterasi dominan biotit-klorit kemudian diikuti oleh serisitlempung.

Berdasarkan pengamatan sementara, terlihat beberapa fase mineralisasi yang berkembang, antara lain:

- Fase epidot-aktinolit yang diikuti mineralisasi magnetit-kalkopirit dan sebagian telah mengalami overprint oleh pirit (Gambar 11).

- Fase biotit-magnetit-kalkopirit-bornit yang berkembang pada urat tipe A dan
AB. Sebagian besar mengalami overprint oleh pirit pada fase akhir (Gambar 12).

- Fase serisit-mineral lempung-pirit yang menggantikan keseluruhan sistem (Gambar 13).

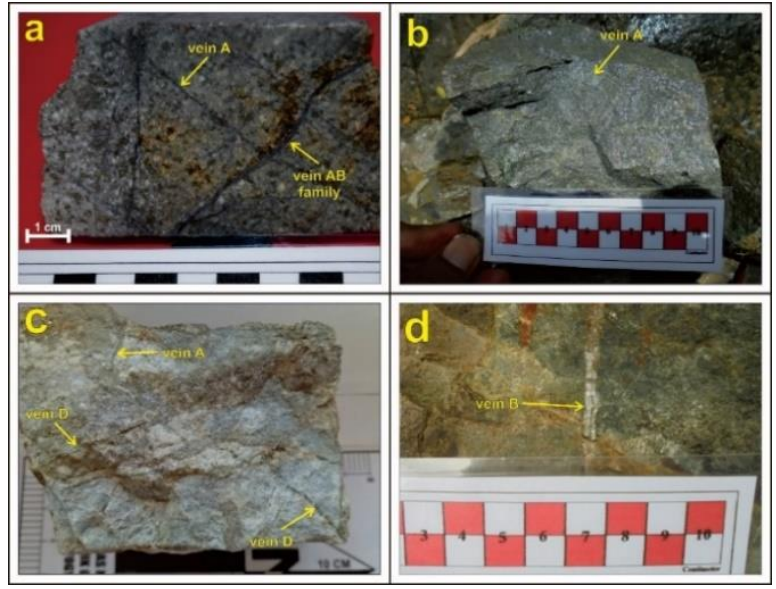

Gambar 10. (a) Stockwork vein A yang terpotong oleh urat $\mathrm{AB}$ pada mikrodiorit; (b) Mineral sulfida berupa pirit yang terdiseminasi pada mikrodiorit dengan urat A; (c) Urat A terpotong oleh urat D yang berasosiasi dengan alterasi ilit-serisit \pm biotit sekunder; (d) Sheted vein $\mathrm{B}$ dicirikan oleh adanya center line sulfida pada mikrodiorit.

$$
\text { Interpretasi paragenesa belum }
$$
sepenuhnya dapat dilakukan karena 
terbatasnya data spasial. Namun, penciri utama porfiri telah dipastikan dengan kehadiran urat kuarsa tipe $\mathrm{A}$ dan $\mathrm{AB}$ diikuti oleh mineralisasi kalkopirit \pm bornit-magnetit yang tersebar di antara kuarsa. Mineral bijih pembawa tembaga berukuran $<40 \mu \mathrm{m}$ dan sulit ditemukan, kemungkinan disebabkan oleh adanya proses mineralisasi epitermal di permukaan.

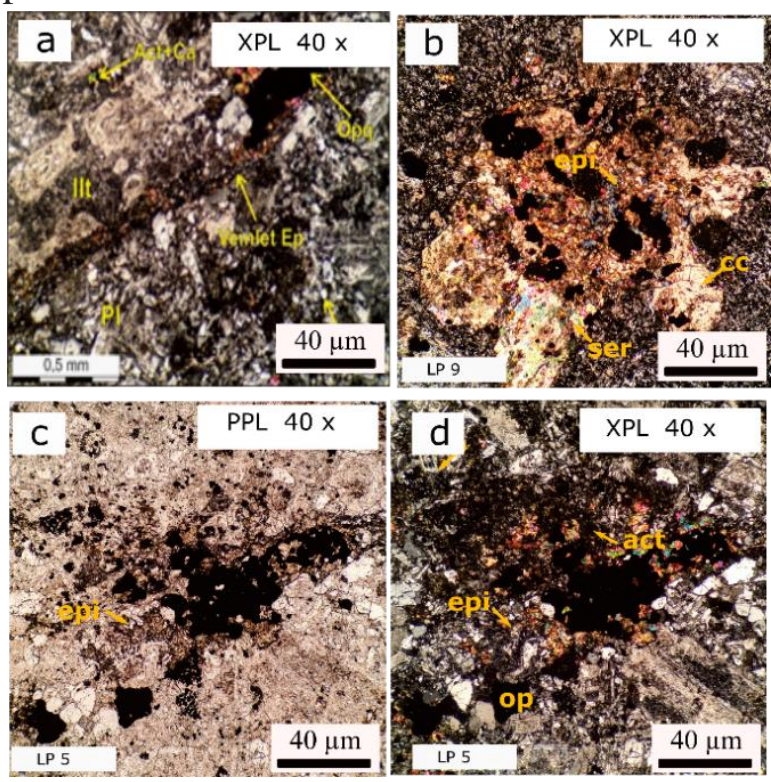

Gambar 11. Kelompok alterasi epidot-aktinolit dan mineralisasi magnetit-pirit yang menggantikan mineral primer mengisi retakan batuan sebagai veinlet; (a) epidot-aktinolit diikuti mineral opak; (b) epidot-kalsitserisit dan magnetit-pirit menggantikan feldspar glomerofenokris; (c-d) magnetit-pirit terakumulasi bersama epidot-aktinolit.

Fase mineralisasi kalkopirit \pm bornit hadir bersama alterasi potasik (biotit-albit-klorit). Mineralisasi ini berkembang secara dominan pada tipe sheeted vein dan sedikit pada tipe stockwork, kemungkinan terpengaruh oleh tektonik pada saat sistem hidrotermal berlangsung. Hal tersebut memberikan kemungkinan mineralisasi berkembang baik di bawah permukaan atau sektor lain yang tidak jauh. Kehadiran tembaga pada fase ini dibuktikan dengan kisaran kadar 0,1-0,14 \% $\mathrm{Cu}$ dan 0,14-0,3 ppm Au pada batuan, meskipun analisis dilakukan pada sampel yang terkena mineralisasi epitermal.
Mineralisasi tembaga-emas tipe porfiri masih terlihat dari jejak kehadiran tekstur awal dan kadarnya di dalam batuan, meskipun mineral sulfida pembawa tembaga sulit dijumpai secara megaskopik.
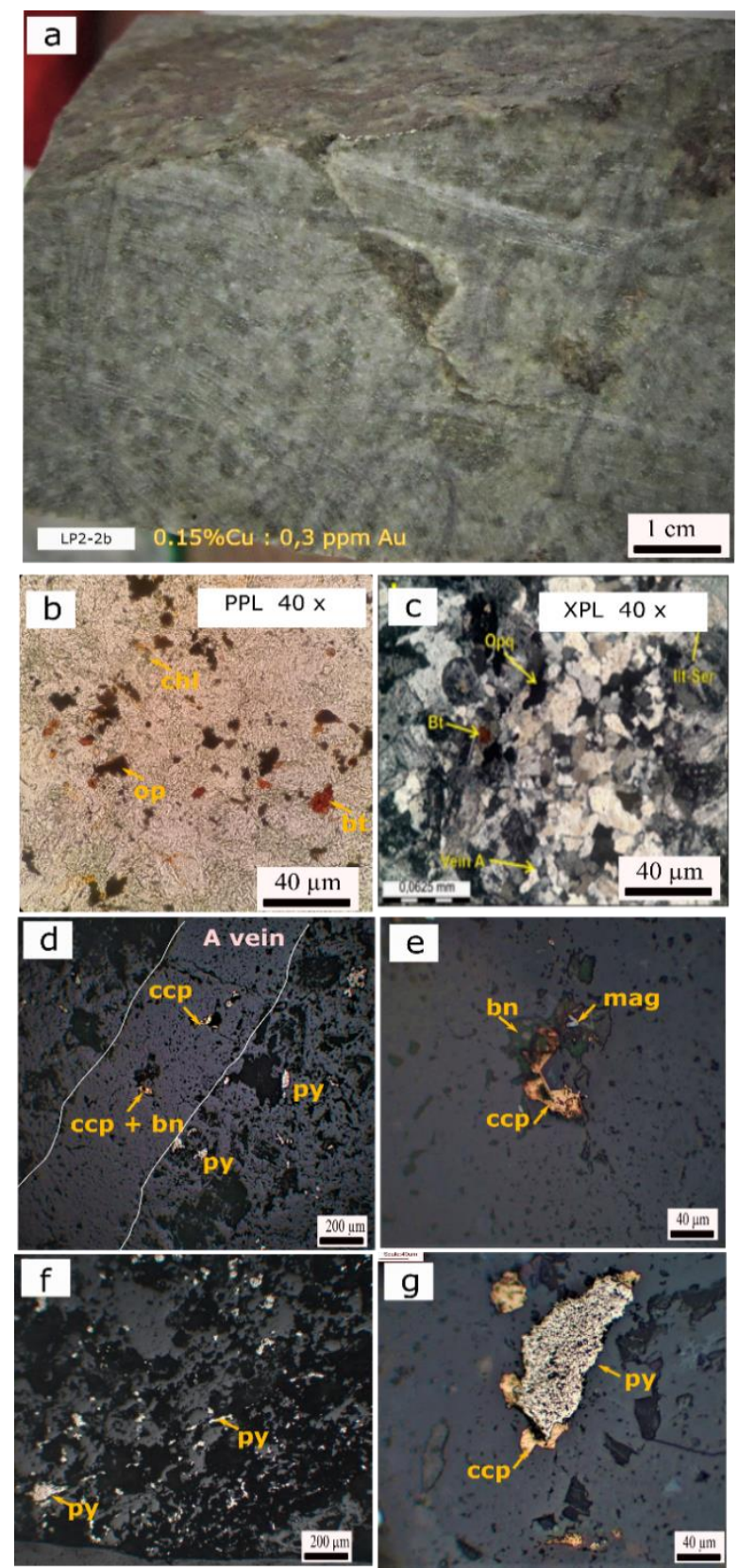

Gambar 12. Mineralisasi fase porfiri yang berkembang pada batuan dioritik disertai stockwork vein kuarsa halus; $(\mathrm{a}-\mathrm{c})$ biotit sekunder dan klorit yang berasosiasi dengan urat A; (d) mineral kalkopirit, bornit yang dijumpai pada urat dan diseminasi pirit pada batuan samping sebagai indikasi sistem lainnya; (e) bornitkalkopirit-magnetit perbesaran dari gambar (d); (f) diseminasi pirit di antara kristal yang mengisi retakan; (g) pirit yang menggantikan kalkopirit. 

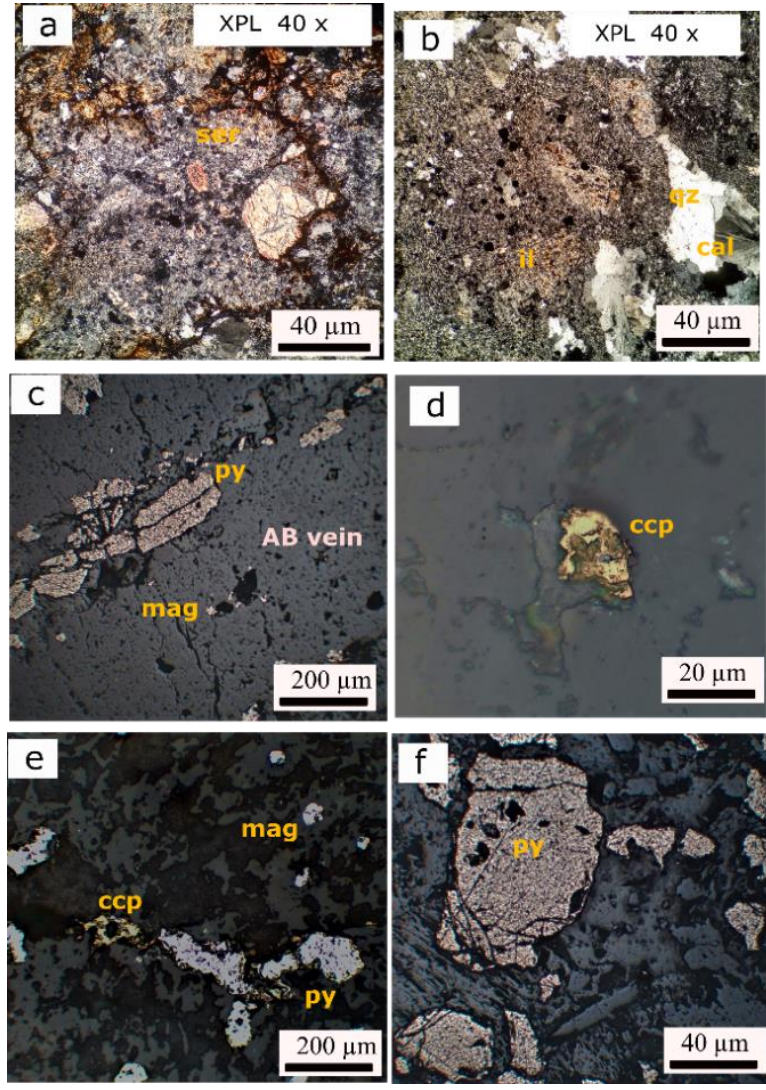

Gambar 13. Alterasi dan mineralisasi pada tahapan akhir; (a) alterasi kaolinit-ilit-smektit pada batuan beku; (b) alterasi ilit diikuti penambahan kuarsa dan kalsedon; (c) pengisian celah paralel pada urat tipe AB oleh pirit; (d) mineralisasi kaya tembaga berupa kalkopirit yang tersisa pada urat kuarsa; (e) mineralisasi tahap awal pada sistem porfiri berupa urat kalkopirit (tipe C) dan diseminasi magnetit yang tergantikan pirit; (f) diseminasi dan kristal pirit yang euhedral sebagai bukti fase epitermal di daerah Sumbersari.

Fase akhir yang terlihat adalah kehadiran alterasi serisit beserta mineral lempung lainnya, seperti illit, kaolinit, dan smektit. Fase ini kemungkinan terpengaruh oleh sistem mineralisasi epitermal yang overprint dengan sistem awal. Pada tahapan ini hadir kuarsa dan kalsedon pada batuan, diikuti dengan diseminasi pirit, baik menggantikan mineral ataupun mengisi retakan pada batuan, serta celah pada urat kuarsa porfiri (Gambar 13). Urat kuarsa ametis barren ditemukan di sekitar singkapan sebagai lensa yang mengisi bukaan kecil pada struktur post-porphyry. Penelitian lanjut belum dilakukan pada tipe ini, tetapi dapat dipastikan tipe ini adalah sistem epitermal yang menyebabkan singkapan dengan tekstur mineralisasi porfiri terganti menjadi epitermal.

Mineralisasi tipe akhir terlihat tidak signifikan mengubah kondisi kandungan tembaga atau emas pada batuan. Hal tersebut terlihat dari kadar logam dasar yang tidak signifikan pada batuan. Semua batuan memiliki kadar $\mathrm{Pb}$ atau $\mathrm{Zn}$ pada kisaran 9-87 ppm. Proses epitermal terlihat dari kehadiran arsen dengan kandungan 90-96 ppm pada batuan. Kondisi geologi yang hadir pada daerah Sumbersari belum dapat dipastikan kronologinya karena belum ada pendataan umur di daerah ini. Magmatisme postporphyry dapat dipastikan dari adanya retas 3-20 m pada andesit basaltik berarah relatif tenggara-barat laut yang menerobos satuan diorit teralterasi. Proses magmatisme dan vulkanisme akhir di daerah Sumbersari khususnya atau kompleks Gunung Gadjah perlu dikaji pada penelitian lainnya untuk menjawab hubungan evolusi dan mineralisasi tersebut.

\section{Geokimia Batuan Beku}

Geokimia batuan beku diperoleh dengan menggunakan metode analisis XRF (Tabel 1) untuk memperoleh data oksida utama pada batuan tidak teralterasi dan pada retas andesit yang relatif terbentuk terakhir. Selain itu, analisis juga dilakukan dengan menggunakan metode ICP-OES (Tabel 2) untuk memperoleh data unsur jejak pada batuan teralterasi hidrotermal. Hasil ploting pada diagram $\mathrm{K}_{2} \mathrm{O}$ vs $\mathrm{SiO}_{2}$ maupun pada diagram Total Alkali Silica (TAS) menunjukan tataan tektoniknya berada pada island-arc dengan afinitas magma kalk-alkali (gambar 14), sebagaimana kondisi umumnya di Kulon Progo [8, 22]. 
Tabel 1. Analisis oksida utama dengan XRF pada batuan andesit basaltik sampel LP-12.

\begin{tabular}{cc}
\hline Oksida Utama & $\%$ \\
\hline $\mathrm{Na}_{2} \mathrm{O}$ & 3,12 \\
$\mathrm{MgO}$ & 7,205 \\
$\mathrm{Al}_{2} \mathrm{O}_{3}$ & 21,22 \\
$\mathrm{SiO}_{2}$ & 53,74 \\
$\mathrm{P}_{2} \mathrm{O}_{5}$ & 0,3488 \\
$\mathrm{~K}_{2} \mathrm{O}$ & 0,9175 \\
$\mathrm{CaO}$ & 8,106 \\
$\mathrm{TiO}_{2}$ & 0,5919 \\
$\mathrm{Fe}_{2} \mathrm{O}_{3}{ }^{\text {total }}$ & 7,353 \\
\hline
\end{tabular}

Tabel 2. Hasil analisis geokimia batuan dengan ICPOES pada batuan mikrodiorit teralterasi biotit \pm kloritserisit-ilit.

\begin{tabular}{ccccc}
\hline Unsur & LP 28 & LP 33 & LP 29 & satuan \\
\hline $\mathrm{Au}$ & 0,14 & 0,02 & 0,30 & $\mathrm{ppm}$ \\
$\mathrm{Ag}$ & 0,7 & $<0,05$ & $<0,5$ & $\mathrm{ppm}$ \\
$\mathrm{Al}$ & 52355 & 48248 & 62465 & $\mathrm{ppm}$ \\
$\mathrm{As}$ & 95 & 95 & 90 & $\mathrm{ppm}$ \\
$\mathrm{Ba}$ & 60 & 157 & 123 & $\mathrm{ppm}$ \\
$\mathrm{Bi}$ & $<5$ & $<5$ & $<5$ & $\mathrm{ppm}$ \\
$\mathrm{Cu}$ & 1387 & 491 & 1447 & $\mathrm{ppm}$ \\
$\mathrm{Ca}$ & 22697 & 19746 & 30262 & $\mathrm{ppm}$ \\
$\mathrm{Co}$ & 2 & 25 & $<2$ & $\mathrm{ppm}$ \\
$\mathrm{Cr}$ & 30 & 41 & 41 & $\mathrm{ppm}$ \\
$\mathrm{Cd}$ & 3 & 3 & 4 & $\mathrm{ppm}$ \\
$\mathrm{Fe}$ & 5,81 & 4,38 & 4,96 & $\%$ \\
$\mathrm{Ga}$ & 18 & 18 & 20 & $\mathrm{ppm}$ \\
$\mathrm{K}$ & 9346 & 11059 & 6628 & $\mathrm{ppm}$ \\
$\mathrm{La}$ & 13 & 15 & 14 & $\mathrm{ppm}$ \\
$\mathrm{Li}$ & 19 & 11 & 14 & $\mathrm{ppm}$ \\
$\mathrm{Mg}$ & 9485 & 6458 & 11967 & $\mathrm{ppm}$ \\
$\mathrm{Mn}$ & 408 & 317 & 675 & $\mathrm{ppm}$ \\
$\mathrm{Mo}$ & 3 & 11 & 1 & $\mathrm{ppm}$ \\
$\mathrm{Na}$ & 18317 & 27921 & 22152 & $\mathrm{ppm}$ \\
$\mathrm{Nb}$ & $<2$ & 2 & 2 & $\mathrm{ppm}$ \\
$\mathrm{Ni}$ & $<5$ & $<5$ & $<5$ & $\mathrm{ppm}$ \\
$\mathrm{P}$ & 812 & 924 & 924 & $\mathrm{ppm}$ \\
$\mathrm{Pb}$ & 20 & 9 & 29 & $\mathrm{ppm}$ \\
$\mathrm{Pd}$ & $<5$ & $<5$ & $<5$ & $\mathrm{ppm}$ \\
$\mathrm{Pt}$ & $<5$ & $<5$ & $<5$ & $\mathrm{ppm}$ \\
$\mathrm{Sb}$ & $<5$ & $<5$ & $<5$ & $\mathrm{ppm}$ \\
$\mathrm{Sc}$ & $<2$ & $<2$ & $<2$ & $\mathrm{ppm}$ \\
$\mathrm{Se}$ & $<5$ & $<5$ & $<5$ & $\mathrm{ppm}$ \\
$\mathrm{Sr}$ & 118 & 167 & 192 & $\mathrm{ppm}$ \\
$\mathrm{Te}$ & 14 & 11 & 10 & $\mathrm{ppm}$ \\
$\mathrm{Ti}$ & 1556 & 1969 & 2088 & $\mathrm{ppm}$ \\
$\mathrm{Tl}$ & $<5$ & $<5$ & $<5$ & $\mathrm{ppm}$ \\
$\mathrm{V}$ & 65 & 16 & 68 & $\mathrm{ppm}$ \\
$\mathrm{W}$ & $<5$ & $<5$ & $<5$ & $\mathrm{ppm}$ \\
$\mathrm{Y}$ & 12 & 16 & 14 & $\mathrm{ppm}$ \\
$\mathrm{Zn}$ & 64 & 46 & 87 & $\mathrm{ppm}$ \\
$\mathrm{Zr}$ & $<5$ & 6 & $<5$ & $\mathrm{ppm}$ \\
\hline & & & &
\end{tabular}

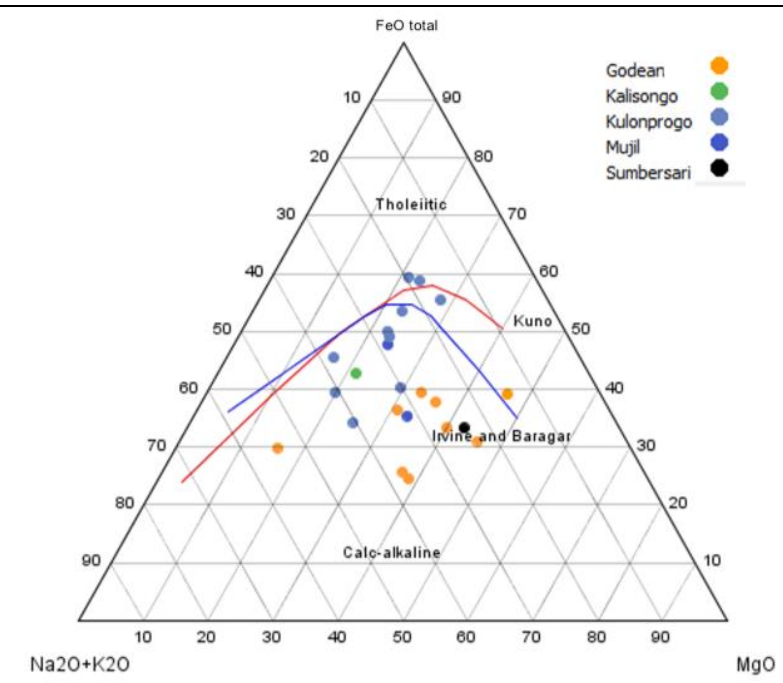

(a)

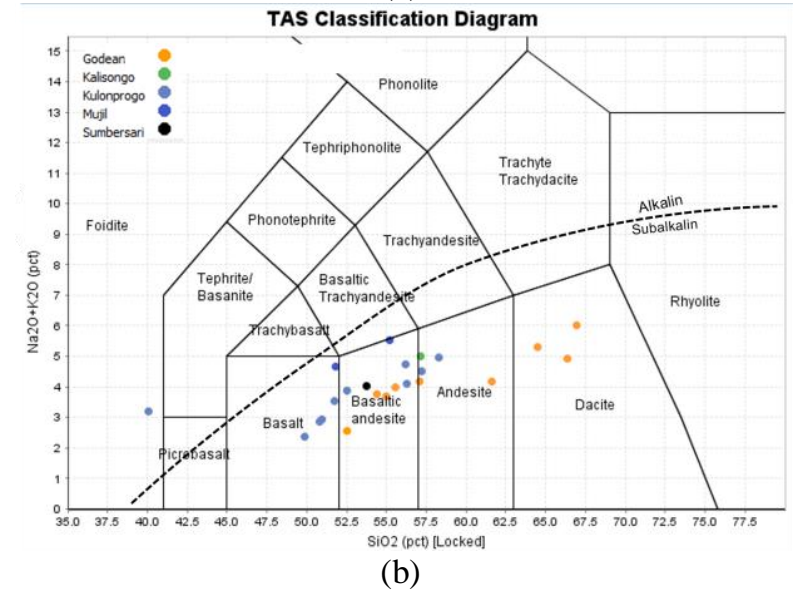

Gambar 14. Ploting oksida utama batuan beku daerah Sumbersari, Kulon Progo, dan Godean [23, 24]; (a) diagram AFM Irvine and Baragar (kurva biru), serta Kuno (kurva merah); (b) Hasil ploting pada diagram $\mathrm{K}_{2} \mathrm{O}$ vs $\mathrm{SiO}_{2}$ [25] dan batas alkali-subalkali [26].

\section{Geokimia Batuan Alterasi Hidrotermal}

Analisis geokimia pada batuan teralterasi menunjukan karakter mineralisasi $\mathrm{Cu}-\mathrm{Au}$ meskipun belum dijumpai kadar ekonomis. Kadar terendah unsur $\mathrm{Cu}$ adalah $491 \mathrm{ppm}$ $(0,05 \%)$ dan tertinggi $1.447 \mathrm{ppm}(0,14 \%)$. Sementara itu, kadar terendah unsur $\mathrm{Au}$ sebesar 0,02 ppm dan tertinggi 0,3 ppm sehingga rasio elemen $\mathrm{Cu}: \mathrm{Au}$ adalah 1,01. Kandungan unsur $\mathrm{Pb}$ dan $\mathrm{Zn}$ pada daerah penelitian berada pada nilai $<100$ ppm menunjukkan bahwa tidak ada pengayaan elemen basemetal di daerah penelitian. Nilai unsur As terlihat memiliki nilai yang cukup 
tinggi. Hal ini dapat diakibatkan karena adanya pengaruh dari sistem lain yang berada di daerah penelitian. Selain itu, kondisi tersebut juga dapat diakibatkan oleh adanya perubahan alterasi di daerah penelitian yang telah mengalami dua fase alterasi.

Karakter geokimia batuan teralterasi dapat dilihat pada nilai dan pola alterasi hidrotermal. Indeks alterasi hidrotermal dapat menggunakan parameter indeks Al-Ca-Na-K (ACNK) [27], Chlorite Calcite Pyrite Index (CCPI) [28], Alteration Index (AI) [29], Muscovite Saturation Index (MSI) [30], Potassic Alteration Index (EPAI) [31], dan Sericite Index (ISER) [32] yang umum digunakan dalam evaluasi sistem alterasi hidrotermal. Kondisi geokimia batuan teralterasi memperlihatkan adanya perubahan dari sistem biotit menuju argilik yang ditandai dengan nilai indeks alterasi hidrotermal (Tabel 3). Sistem ini juga terlihat pada pola kelompok geokimia dari berbagai indeks alterasi hidrotermal (gambar 15), yaitu pengayaan tembaga $(\mathrm{Cu})$ berbanding lurus dengan meningkatnya indeks alterasi CCPI dan ACNK. Karakter geokimia batuan teralterasi umumnya memperlihatkan pola alterasi kelompok felspar dan biotit, kemudian diikuti alterasi kelompok mineral lempung sebagai indikasi adanya proses overprint ataupun supergen (gambar 16).

Tabel 3. Nilai indeks alterasi hidrotermal

\begin{tabular}{|c|c|c|c|c|c|c|c|}
\hline No & $\begin{array}{c}\text { Kode } \\
\text { sampel }\end{array}$ & ACNK & CCPI & AI & MSI & EPAI & ISER \\
\hline 1 & LP. 27 & 1,16 & 56,83 & 26,91 & 0,47 & 0,49 & 18,89 \\
\hline 2 & LP.3 & 1,05 & 60,06 & 50,31 & 1,36 & 0,72 & 54,88 \\
\hline 3 & LP. 2 & 1,46 & 71,55 & 32,34 & 0,37 & 0,21 & 23,08 \\
\hline 4 & LP-2-2 & 1,44 & 68,99 & 31,90 & 0,34 & 0,19 & 21,67 \\
\hline 5 & LP.2.2.b & 1,47 & 68,86 & 27,82 & 0,22 & 0,13 & 14,96 \\
\hline \multicolumn{8}{|c|}{$A C N K=A l 2 O 3 /(\mathrm{Na} 2 \mathrm{O}+\mathrm{CaO}+\mathrm{K} 2 \mathrm{O})$} \\
\hline \multicolumn{8}{|c|}{$\mathrm{CCPI}=100 *(\mathrm{MgO}+\mathrm{FeO}) /(\mathrm{MgO}+\mathrm{Na} 2 \mathrm{O}+\mathrm{FeO}+\mathrm{K} 2 \mathrm{O}$} \\
\hline \multicolumn{8}{|c|}{$A I=100 *(\mathrm{MgO}+\mathrm{K} 2 \mathrm{O}) / \mathrm{MgO}+\mathrm{Na} 2 \mathrm{O}+\mathrm{CaO}+\mathrm{K} 2 \mathrm{O})$} \\
\hline \multicolumn{8}{|c|}{$M S I=(3 * 2 * K 2 O /(94.195)) /(2 * A l 2 O 3 /(101.961276)$} \\
\hline \multicolumn{8}{|c|}{$E P A I=2 * K 2 O /(94.196) /(2 * A l 2 O 3 /(101.961276)-2 * N a 2 O /(61.97894)$} \\
\hline \multicolumn{8}{|c|}{$I S E R=100 *(2 * K 2 O /(94.196)) / 2 * N a 2 O /(61.97894)+2 * K 2 O /(94.196))$} \\
\hline
\end{tabular}
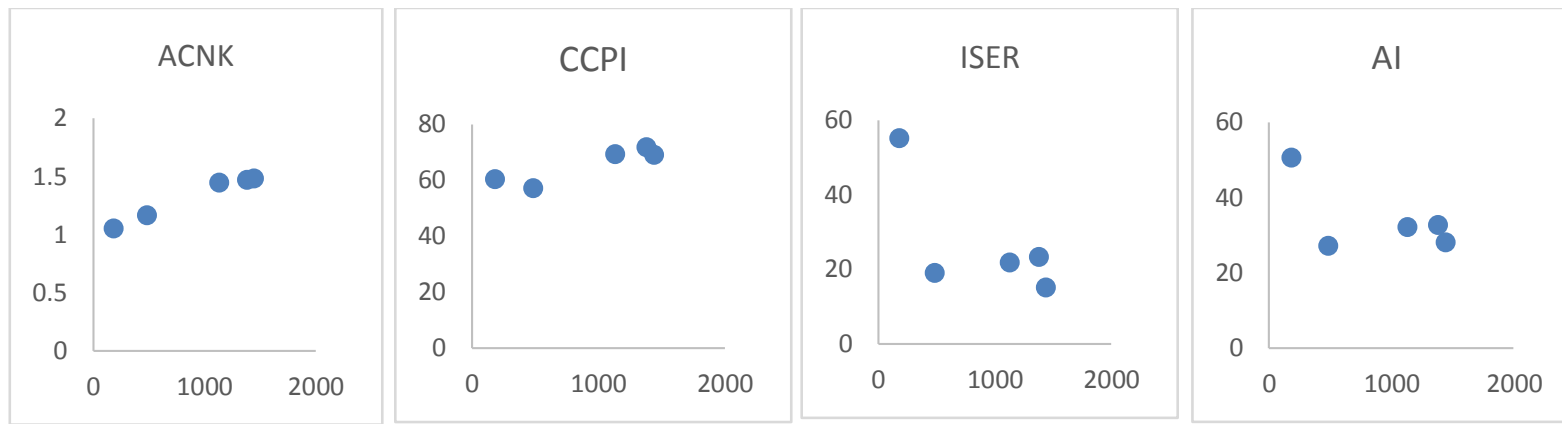

Gambar 15. Grafik korelasi Cu (nilai x) dan indeks alterasi (sumbu Y). Pengayaan Cu terlihat mengikuti kenaikan indeks ACNK [27] dan CCPI [28]. Indeks ACNK merupakan perbandingan antara aluminan dengan Na-Ca-K yang menunjukkan adanya perusakan mineral seperti felspar pada kelompok alterasi sehingga semakin kuat alterasi maka nilai $\mathrm{Cu}$ semakin tinggi. 


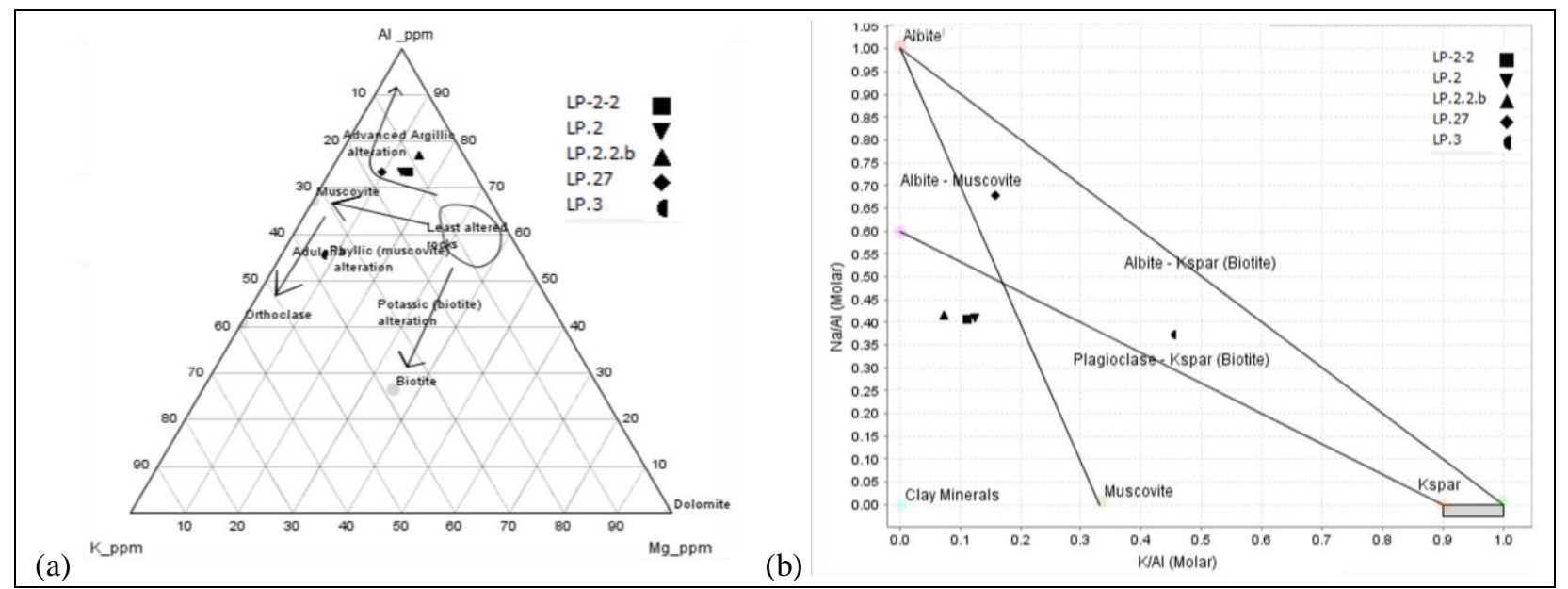

Gambar 16. Posisi sampel batuan teralterasi daerah Sumbersari pada (a) diagram perubahan relatif mineralogi berdasarkan nilai $\mathrm{K}-\mathrm{Mg}-\mathrm{Al}$ [33]; dan (b) grafik rasio alkali alumina dari data $\mathrm{Na} / \mathrm{Al}$ dan $\mathrm{K} / \mathrm{Al}$ molar [34].

\section{KESIMPULAN}

Mineralisasi di daerah Sumbersari, Pegunungan Kulon Progo terbentuk pada batuan intrusi mikrodiorit dan diorit kuarsa sebagai bagian dari magmatisme Miosen. Alterasi hidrotermal yang dijumpai menunjukan indikasi mineralisasi porfiri kuat yang mengalami overprint epitermal pada fase terakhir. Kadar $\mathrm{Cu}$ dan $\mathrm{Au}$ berkisar antara 491-1447 ppm (0,14\%) dan 0,02-0,3 ppm dengan rasio elemen $\mathrm{Cu}: \mathrm{Au}$ adalah 1,01. Karakter geokimia menunjukkan adanya korelasi $\mathrm{Cu}$ terhadap $\mathrm{Au}$ dan penguatan positif pada indeks alterasi hidrotermalnya.

\section{UCAPAN TERIMA KASIH}

Penelitian ini merupakan bagian dari hasil penelitian internal LP3M-ITNY tahun anggaran 2020. Peneliti ingin mengucapkan terimakasih kepada rekan akademisi ITNY atas diskusi dan saran-sarannya, Badan Tenaga Nuklir Nasional (BATAN), Unit Geomin - PT. Antam (persero) Tbk, Mas Reynaldo dan rekan mahasiswa ITNY lainnya atas bantuan data lapangannya.

\section{DAFTAR PUSTAKA}

[1] A. Maryono, R. L. Harrison, D. R. Cooke, I. Rompo, dan T. G. Hoschke, "Tectonics and Geology of Porphyry $\mathrm{Cu}-\mathrm{Au}$ Deposits along the Eastern Sunda Magmatic Arc, Indonesia," Economic Geology, 113(1), pp. 7-38, 2018, doi: 10.5382/econgeo.2018.4542.

[2] S. Garwin, "District-Scale Expression of Intrusion-Related Hydrothermal Systems near the Batu Hijau Porphyry Copper-Gold Deposit, Sumbawa, Indonesia," Proceedings of Banda and Eastern Sunda Arcs 2012 MGEI Annual Convention, pp. 133-158, 2012.

[3] A. S. Ubaidillah, A. Idrus, I. W. Warmada, dan S. Maula, "Geokimia pada Endapan $\mathrm{Cu}$-Au Porfiri Brambang Pulau Lombok, Nusa Tenggara Barat, " Geosapta, 5(2), pp. 103-113, 2019.

[4] R. L. Harrison, A. Maryono, M. S. Norris, dan B. D. Rohrlach, "Geochronology of the Tumpangpitu Porphyry Au-Cu-Mo and HighSulfidation Epithermal $\mathrm{Au}-\mathrm{Ag}-\mathrm{Cu}$ Deposit: Evidence for Pre- and Postmineralization Diatremes in the Tujuh Bukit District, Southeast Java, Indonesia," Economic Geology, 113(1), pp. 163-192, 2018, doi: 10.5382/econgeo.2018.4547.

[5] PT Sumbawa Timur Mining, "Mineral Resource Estimate Statement : Hu'u Project, Onto CopperGold Deposit, Nusa Tenggara Barat Province Indonesia," 2019.

[6] A. Muthi, I. G. Basten, I. G. M. Suasta, dan N. E. W. Litaay, "Characteristics of Alteration and Mineralization at Randu Kuning - Wonogiri Project," Proceedings of Banda and Eastern Sunda Arcs 2012 MGEI Annual Convention, pp. 117-133, 2012.

[7] L. D. Setijadji, S. Kajino, A. Imai, dan K. Watanabe, "Cenozoic Island Arc Magmatism in Java Island ( Sunda Arc, Indonesia ): Clues on Relationships between Geodynamics of Volcanic 
Centers and Ore Mineralization," Resource Geology, 56(3), pp. 267-292, 2008, doi: 10.1111/j.1751-3928.2006.tb00284.x.

[8] A. Harjanto, E. Suparka, S. Asikin, dan Y. S. Yuwono, "Magmatic Related to Hydrothermal Alteration in Kulon Progo, Central Java, Indonesia," Proceeding International Interdisciplinary Conference Volcano International Gathering, 2006.

[9] S. Prihatmoko dan A. Idrus, "Low-Sulfidation Epithermal Gold Deposits in Java, Indonesia: Characteristics dan Linkage to the VolcanoTectonic Setting," Ore Geology Reviews, 121, p. 103490, 2020, doi: 10.1016/j.oregeorev.2020.103490.

[10] D. Pambudi, T. Winarno, dan Y. Aribowo, "Geologi dan Mineralisasi Logam Daerah Sangon, Kokap, Kulon Progo, Daerah Istimewa Yogyakarta," Jurnal Geosains dan Teknologi, 1(2), 2018, doi: 10.14710/jgt.1.2.2018.74-80.

[11] L. A. Prasetyo, Fadlin, Siswandi, W. T. Anggoro, dan A. Oktaviany, "Pre-Eliminary Study High Sulphidation Epithermal Gold And Possibility Porphyry System in the Southern Part Of Kulonprogo Dome- Hargerejo- BagelenPurworejo," in JCM HAGI-IAGI-IAFMI-IATMI, 2017.

[12] A. Idrus, I. W. Warmada, dan R. I. Putri, "Mineralisasi Emas di Gunung Gupit, Magelang, Jawa Tengah: Sebuah Penemuan Baru Prospek Emas Tipe Ephitermal Sulfidasi Tinggi pada Rangkaian Pegunungan Kulon Progo-Menoreh," in Annual Engineering Seminar 2013, Yogyakarta, 2013.

[13] O. Verdiansyah, “A Desktop Study to Determine Mineralization Using Lineament Density Analysis at Kulon Progo Mountains, Yogyakarta and Central Java Province, Indonesia," Indonesian Journal of Geography, 51(1), pp. 3141, 2019, doi: 0.22146/ijg.37442.

[14] A. Harjanto, "Petrologi dan Geokimia Batuan Volkanik di Daerah Kulonprogo dan sekitarnya Daerah Istimewa Yogyakarta," Jurnal Ilmiah MTG, 4(1), 2011.

[15] H. G. Hartono, "Peran Paleovolkanisme dalam Tataan Produk Batuan Gunung Api Tersier di Gunung Gajahmungkur, Wonogiri, Jawa Tengah," Disertasi Doktor, Fakultas Teknologi Mineral, University Padjadjaran, Bandung, 2010.

[16] W. Rahardjo, Sukandarrumidi, dan H. Rosidi, "Yogyakarta Sheet Geological Map scale 1:100.000," Bandung: Geological Research and Development Center, 1995.

[17] D. H. Barianto, P. Kuncoro, dan K. Watanabe, "The Use of Foraminifera Fossils for Reconstructing the Yogyakarta Graben, Yogyakarta, Indonesia," Journal of SE Asian Applied Geology, 2(2), pp. 138-143, 2010, doi: 10.22146/jag.7256.
[18] I. Syafri, E. Budiadi, dan A. Sudradjat, "Geotectonic Configuration of Kulon Progo Area, Yogyakarta Konfigurasi Tektonik Daerah Kulon Progo, Yogyakarta," Indonesian Journal of Geology, 8(4), pp. 185-190, 2013.

[19] R. Hall, B. Clements, H. R. Smyth, dan M. A. Cottam, "A New Interpretation of Java's Structure," Indonesian Petroleum Association$31^{\text {st }}$ Annual Convention Proceedings, 2007, doi: 10.29118/ipa.1077.g.035.

[20] S. Husein dan M. Nukman, "Rekonstruksi Tektonik Mikrokontinen Pegunungan Selatan Jawa Timur: Sebuah Hipotesis berdasarkan Analisis Kemagnetan Purba," Prosiding Seminar Nasional Kebumian ke-8 Jurusan Teknik Geologi FT-UGM, 2015, doi: 10.13140/RG.2.1.3325.5126.

[21] A. Widagdo, S. Pramumijoyo, dan A. Harijoko, "The Morphotectono-Volcanic of MenorehGajah-Ijo Volcanic Rock In Western Side of Yogyakarta-Indonesia," Journal of Geoscience Engineering Environment and Technology, 3(3), p. 155, 2018, doi: 10.24273/jgeet.2018.3.3.1715.

[22] R. Soeria-Atmadja, R. C. Maury, H. Bellon, H. Pringgoprawiro, M. Polve, dan B. Priadi, "Tertiary Magmatic Belts in Java," Journal of Southeast Asian Earth Sciences, 9(1-2), pp. 1327, 1994, doi: 10.1016/0743-9547(94)90062-0.

[23] O. Verdiansyah, "Perubahan Unsur Geokimia Batuan Hasil Alterasi Hidrotermal di Gunung Wungkal, Godean, Yogyakarta," Kurvatek, 1(1), pp. 59-67, 2016, doi: 10.33579/krvtk.v1i1.198.

[24] O. Verdiansyah, dan H. G. Hartono, "Mineralogy and Geochemistry Analysis of the Igneous Rocks to Strengthen the Hypothesis of Mujil Hill as a Monogenetic Paleo-Volcano," in Joint Convention Yogyakarta, 2019.

[25] R. W. Le Maitre, A. Streckeisen, B. Zanettin, M. J. Le Bas, B. Bonin, dan P. Bateman, Igneous rocks: A Classification and Glossary of Terms, Recommendations of the International Union of Geological Sciences Subcommission on the Systematics of Igneous Rocks, 2nd ed. New York, United States: Cambridge University Press, 2002, doi: 10.1017/CBO9780511535581.

[26] H. R. Rollinson, Using Geochemical Data: Evaluation, Presentation, Interpretation. London: Routledge, 1993

[27] E. C. Grunsky, "Predicting Archaean Volcanogenic Massive Sulphide Deposit Potential from Lithogeochemistry: Application to the Abitibi Greenstone Belt" Geochemistry: Exploration, Environment, Analysis, 13(4), pp. 317-336, 2013, doi: 10.1144/geochem2012-176.

[28] J. B. Gemmell, "Hydrothermal Alteration Associated with the Gosowong Epithermal $\mathrm{Au}-$ Ag deposit, Halmahera, Indonesia: Mineralogy, Geochemistry, and Exploration Implications," Economic Geology, 102(5), pp. 893-922, 2007, doi: 10.2113/gsecongeo.102.5.893. 
[29] Y. Ishikawa, T. Sawaguchi, S. Iwaya, dan M. Horiuchi. "Delineation of Prospecting Targets for Kuroko Deposits based on Modes of Volcanism of Underlying Dacite and Alteration Halos," Mining Geology, 26, pp. 10-117, 1976, doi: 10.11456/shigenchishitsu1951.26.105.

[30] A. Kishida dan R. Kerrich,"Hydrothermal Alteration Zoning and Gold Concentration at the Kerr- Addison Archean lode Gold Deposit, Kirkland Lake, Ontario (Canada)," Economic Geology, vol. 82, pp. 649-690, 1987, doi: 10.2113/gsecongeo.82.3.649.

[31] M. A.Whitbread dan C. L. Moore, "Two Lithogeochemical Approaches to the Identification of Alteration Patterns at the Elura $\mathrm{Zn}-\mathrm{Pb}-\mathrm{Ag}$ Deposit, Cobar, New South Wales, Australia: Use of Pearce Element Ratio Analysis and Isocon Analysis," Geochemistry: Exploration, Environment, Analysis, 4(2), pp.
129-141, 2004, doi: 10.1144/1467-7873/03-031.

[32] Y. Saeki dan J. Date, "Computer Application to the Alteration Data of the footwall Dacite Lava at the Ezuri Kuroko Deposits, Akita Prefecture," Mining Geology, 30(162), pp. 241-250, 1980, doi: 10.11456/shigenchishitsu1951.30.241.

[33] S. Halley, D. Wood, A. Stoltze, J. Godfroid, H. Goswell, dan D. Jack, 2016, "Using Multielement Geochemistry to Map Multiple Components of a Mineral System: Case Study from a SedimentHosted Cu-Ni Camp, NW Province, Zambia," Society of Economic Geologists Newsletter, no. 104, pp. 14-21, 2016.

[34] J. F. Davies dan R. E. Whitehead, "AlkaliAlumina and $\mathrm{MgO}$-Alumina Molar Ratios of Altered and Unaltered Rhyolites," Exploration and Mining Geology, 15(1), pp. 75-88, 2006, doi: 10.2113/gsemg.15.1-2.75. 